CLINICAL STUDY

\title{
Long-term outcome in patients with acromegaly: analysis of 1344 patients from the German Acromegaly Register
}

Christof Schöfl, Holger Franz ${ }^{1}$, Martin Grussendorf ${ }^{2}$, Jürgen Honegger ${ }^{3}$, Cornelia Jaursch-Hancke ${ }^{4}$, Bernhard Mayr, Jochen Schopohl ${ }^{5}$ and the participants of the German Acromegaly Register

Division of Endocrinology and Diabetes, Department of Medicine I, Friedrich-Alexander-University Erlangen-Nuremberg, Ulmenweg 18, 91054 Erlangen, Germany, ${ }^{1}$ Lohmann and Birkner Health Care Consulting GmbH, Berlin, Germany, ${ }^{2}$ Center of Endocrinology and Diabetes, Stuttgart, Germany,

${ }^{3}$ Department of Neurosurgery, Eberhard Karls University, Tuebingen, Germany, ${ }^{4}$ Department of Endocrinology, German Clinic of Diagnostics, Wiesbaden, Germany and ${ }^{5}$ Department of Internal Medicine IV, Ludwig-Maximilians University Munich, Munich, Germany

(Correspondence should be addressed to C Schöfl; Email: christof.schoefl@uk-erlangen.de)

\begin{abstract}
Background: Acromegaly is a rare disease with significant morbidity and increased mortality. Epidemiological data about therapeutic outcome under 'real life' conditions are scarce. Objective: To describe biochemical long-term outcome of acromegaly patients in Germany. Design and methods: Retrospective data analysis from 1344 patients followed in 42 centers of the German Acromegaly Register. Patients' data were collected 8.6 (range 0-52.6) years after diagnosis. Controlled disease was defined by an IGF1 within the center-specific reference range.

Results: Nine hundred and seventeen patients showed a normalized IGF1 (157 (range 25-443) ng/ml). In patients with a diagnosis dated back $>2$ years $(n=1013)$, IGF1 was normalized in $76.9 \%$. Of the patients, $19.5 \%$ had an elevated IGF1 and a random GH $\geq 1 \mathrm{ng} / \mathrm{ml}, 89 \%$ of the patients had at least one surgical intervention, 22\% underwent radiotherapy, and 43\% received medical treatment. After surgery $38.8 \%$ of the patients were controlled without any further therapy. The control rates were higher in surgical centers with a higher caseload $(P=0.034)$. Of the patients with adjunctive radiotherapy $34.8 \%$ had a normal IGF1 $8.86(0-44.9)$ years post irradiation, $65.2 \%$ of the medically treated patients were controlled, and $47.2 \%$ of the patients with an elevated IGF1 received no medical therapy.

Conclusion: The majority of acromegaly patients were controlled according to their IGF1 status. Longterm outcome could be improved by exploiting medical treatment options especially in patients who are not controlled by surgery and/or radiotherapy.
\end{abstract}

European Journal of Endocrinology 168 39-47

\section{Introduction}

Acromegaly is caused by excessive $\mathrm{GH}$ secretion from benign pituitary tumors in the vast majority of cases (1). GH excess and excessive production of insulin-like growth factor 1 (IGF1) is associated with increased morbidity, impaired quality of life, and reduced life expectancy (1). However, when GH-excess is controlled and/or IGF1 levels are normalized, the clinical symptoms and comorbidities improve $(1,2)$ and mortality risk can be markedly reduced toward that of the normal population $(3,4)$. The aim of therapy is normalization of GH and IGF1 levels $(1,2)$.

According to current consensus guidelines, transsphenoidal surgery is the treatment of choice as it is at the present time the only option to cure the disease (5). Normalization of IGF1 can be expected in $75-95 \%$ of patients with a microadenoma, if the operation is performed by an experienced neurosurgeon $(5,6,7,8$, 9 ). Control rates, however, are substantially lower in patients with macroadenomas (40-69\%) even in experienced centers (7). If surgery is contraindicated or if disease activity persists postoperatively, medical treatment is the most common second line approach (5). Somatostatin analogs (SSAs), dopamine agonists (DAs), and a GH receptor antagonist (GHRA) are currently available for pharmacological treatment. They are either used in monotherapy or in various combinations. Radiotherapy is another therapeutic option that should generally be considered as third line therapy (5). Normalization of IGF1 has been reported in up to $60 \%$ of cases 10-15 years after conformal fractionated radiotherapy $(10,11,12)$. For single-dose radiosurgery, 5-year remission rates range from $29-60 \%$ according to the literature $(13,14,15)$. Concerns about long-term safety, however, are the main limitation to a more widespread use in acromegaly (5). Taken together, disease control should be achievable by currently available treatment options in the vast majority of acromegalic patients. Information about 
control or cure rates, however, comes from expert centers or randomized clinical trials that may not reflect treatment reality under 'real-life' conditions in dayto-day care.

As acromegaly is a rare disease, epidemiological data with regard to treatment strategies and long-term outcome are scarce. Several national data registries collecting data of patients with acromegaly have been initiated to observe 'real-life' long-term outcome (12, $16,17,18,19,20,21,22,23,24)$. Patients' outcome is not only affected by the efficacy of individual treatment options but also by the organization and funding of national health care systems. The system in Germany is pluralistic and the care of acromegalic patients is distributed over many academic and non-academic hospital settings as well as private practices. The aim of the current analysis of the German Acromegaly Register was to describe the biochemical outcome of acromegaly under the 'real-life' conditions of the national health care system. These data are a prerequisite for further improvements in the treatment and cost-effective management of acromegaly and are the basis to establish the most effective treatment plans.

\section{Subjects and methods}

The German Acromegaly Register is a nationwide register established in 2003 by the Pituitary Disease Study Group on behalf of the German Endocrine Society. The register performs an epidemiological, retrospective study on the diagnosis, treatment, and follow-up of patients with acromegaly in Germany. Details about the structure, database, and data collection have been published previously $(19,25,26)$. Written informed consent has been obtained from the patients included in the present survey. The protocol of the register has been approved by the Ethics Committee of the CharitéUniversitätsmedizin Berlin, Germany, and by the Berlin commissioner for data protection and freedom of information.

\section{Patient selection and outcome definition}

Patients, who had at least one recorded visit and data entry into the database within the last 3 years, were selected from the database of 3081 patients enrolled in the German Acromegaly Register at the time of the analysis in 2010/11. Disease control was assumed, if the locally measured IGF1 levels were below the upper limit of normal of the center-specific, age-, and genderadjusted reference range. Patients with an IGF1 below the reference range, e.g. caused by treatment associated GH-deficiency, were also regarded as controlled. Active disease was defined as an IGF1 value above the center-specific reference range. In Germany, regular nationwide interlaboratory comparison testings are mandatory for clinical laboratories to participate in patients' care, which assures a high-quality standard. IGF1 is a sensitive measure of integrated GH production and closely correlates with clinical, metabolic, and endocrine markers of disease activity. Normalization of IGF1 is associated with reduced morbidity and normal life expectancy $(3,4,27)$. Furthermore, in patients who are treated with the GHRA pegvisomant, normalization of IGF1 is the only marker of disease control $(27,28)$. The most recent criteria for disease control in acromegaly, in addition to normalization of IGF1, also require a random $\mathrm{GH}<1 \mathrm{ng} / \mathrm{dl}$ using an ultrasensitive GH assay (28). Random GH values as either single determinations or as the first value of a profile or an oral glucose tolerance test are also documented in the register although in fewer patients. Since commercial GH-assays show a high interassay variability, the use of a given threshold for all centers to define disease control could therefore be misleading $(29,30)$. As many centers guide their long-term treatment decisions especially in medically treated patients on IGF1 levels and in order to uniform the outcome definition for all treatment modalities, we used IGF1 normalization as the outcome parameter to define disease control in this nationwide retrospective analysis.

\section{Statistical analysis}

Statistical analyses were performed using SigmaPlot version 11, Systat Software (Erkrath, Germany). Results are given as mean \pm s.D. (normally distributed data) or median plus range (non-normally distributed data). The Shapiro-Wilk test was used to test for normal distribution. Comparisons between datasets were done by the Mann-Whitney $U$ test or the Kruskal-Wallis test. Significance was considered at $P<0.05$.

\section{Results \\ Patients}

The study cohort included 1344 patients, of which 775 were females $(57.6 \%)$ and 569 males $(42.3 \%)$, with a median age of 47 (range 15-86) and of 41 (range 9-78) years respectively at diagnosis $(P<0.001)$. For 64 patients, the age at initial diagnosis was not available (42 women, 22 men). A pituitary macroadenoma was documented in 683 patients, 139 patients had a microadenoma, and in 22 patients no tumor could be delineated on imaging studies. In 500 patients no information about tumor size was available. All patients had a documented follow-up visit within the last 3 years and were treated in 42 centers participating in the German Acromegaly Register (19 university hospitals, 11 community hospitals, and 12 endocrine practices). Median age at the time of the survey was 58 (range 19-89) for female and 53 (range 9-85) years for male patients $(P<0.001)$. Patients' data were collected 8.6 


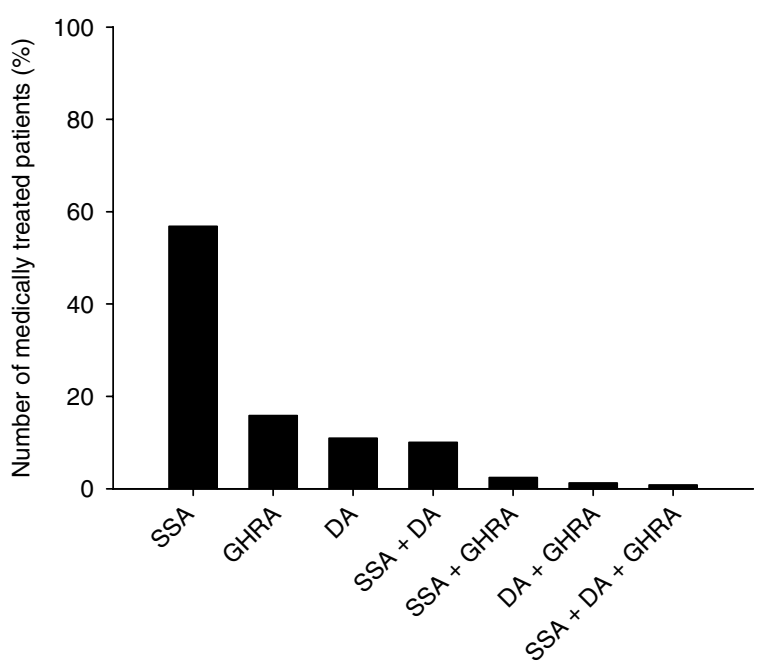

Figure 1 Drug therapies used in medically treated patients $(n=573)$ in the German Acromegaly Register. Patients were treated with somatostatin analogs (SSAs), GH receptor antagonist (GHRH), dopamine agonists (DAs), or various combinations.

(range 0-52.6) years after the initial diagnosis. In 1068 patients, the diagnosis of acromegaly was made more than 2 years before the survey, whereas 211 patients were diagnosed within 2 years of data acquisition including 19 newly diagnosed cases.

\section{Therapy}

During the course of their disease, 1200 patients $(89.3 \%)$ had at least one surgical intervention and 298 patients $(22.2 \%)$ had received radiotherapy, mostly as an adjunctive therapy after surgery $(n=276)$. At the last follow-up, 573 patients $(42.6 \%)$ were treated medically: 407 patients $(30.3 \%)$ received SSAs, 140 patients $(10.4 \%)$ DAs, and 122 patients $(9.1 \%)$ were under a medication with the GHRA pegvisomant. Ninety patients were treated with various drug combinations. The different drug therapies used in medically treated patients are depicted in Fig. 1. In the 1068 patients with long-standing disease (diagnosis more than 2 years), 971 patients (90.9\%) had at least one operation: $84(7.9 \%)$ patients had no surgery and were treated medically and/or had received radiotherapy $(n=20)$. In 13 patients $(1.2 \%)$ no therapy was documented. In the 211 patients with a more recent diagnosis of acromegaly ( $\leq 2$ years), 173 already had an operation. Amongst the 38 patients without surgery, there were 19 newly diagnosed cases and 21 patients received medical therapy. None of these 38 patients had radiotherapy.

\section{Biochemical outcome}

At the last follow-up visit, IGF1 levels were available in 1275 of the 1344 patients. In 917 patients IGF1 was reported to be normalized with a median of 157 (range 25-443) $\mathrm{ng} / \mathrm{ml}$, while in 358 patients IGF1 was elevated (median 349 (range 156-1195) $\mathrm{ng} / \mathrm{ml}$, $P<0.001)$. In the 1013 patients in whom diagnosis of acromegaly was made $>2$ years before the survey, $76.9 \%(n=779)$ were reported to have a normal IGF1. By contrast, in the 199 patients who were diagnosed $\leq 2$ years before the survey, only $47.2 \%$ of the patients had a normal IGF1.

\section{Surgery and biochemical outcome}

Transsphenoidal surgery was the standard operation in the vast majority of cases $(n=925), 50$ patients were operated via the transcranial route, and in 225 patients the type of surgery was not documented. IGF1 was available for 1138 of the 1200 patients that had at least one operation. The time of the last follow-up visit was 9.07 (range 0-51.5) years post surgery. At the last follow-up visit, and 442 patients $(38.8 \%)$ had a normal IGF1 just by surgical interventions without adjunctive radiotherapy or medical treatment. The neurosurgical site of the first operation was documented in 947 patients and comprised 76 different neurosurgical units in Germany. In 252 patients, this information was lacking. In neurosurgical units with $\leq 10$ documented surgical cases of the survey cohort, IGF1 was normalized in $28.9 \%$ of the patients. In neurosurgical centers, however, with 11-29 or $\geq 30$ cases, IGF1 normalization was significantly higher $(P=0.034)$ although the scatter was considerable (Table 1 , Fig. 2). In the patient group with unknown surgical site, IGF1 normalization was reached in $28.6 \%$ of the patients.

\section{Radiotherapy and biochemical outcome}

Post surgery 276 patients received adjuvant radiotherapy. In 267 patients, an IGF1 was documented at the time of the survey, which was on average 8.9 (range 0-44.9) years post irradiation. Ninety-three patients (34.8\%) had a normal IGF1 without further medical treatment. In patients who were treated by radiotherapy more than 10 years before the survey $(n=55,16.5$

Table 1 Rates of normal IGF1 in operated patients with no adjunctive radiotherapy or medical treatment at the time of the survey stratified by centers with $\leq 10,11-29$, and $\geq 30$ documented surgical cases of the survey cohort. The difference between the groups was statistically significant $(P=0.034)$.

\begin{tabular}{lccc}
\hline $\begin{array}{l}\text { Number of } \\
\text { surgical } \\
\text { cases per } \\
\text { center }\end{array}$ & $\begin{array}{c}\text { Number of } \\
\text { neurosurgical } \\
\text { units }\end{array}$ & $\begin{array}{c}\text { Total number } \\
\text { of patients } \\
\text { treated }\end{array}$ & $\begin{array}{c}\text { Number of } \\
\text { patients with } \\
\text { normal IGF1 } \\
(\%)\end{array}$ \\
\hline$\leq 10$ & 53 & 170 & 28.9 \\
$11-29$ & 17 & 315 & 35.7 \\
$\geq 30$ & 6 & 454 & 49.8 \\
\hline
\end{tabular}




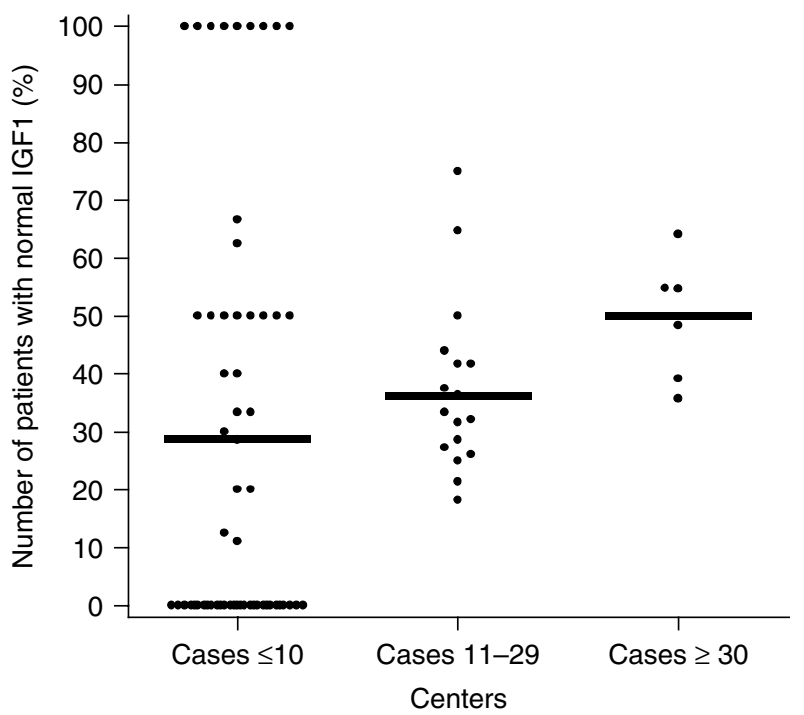

Figure 2 Rates of normal IGF1 in operated patients with no adjunctive radiotherapy or medical treatment at the time of the survey stratified by centers with $\leq 10,11-29$, and $\geq 30$ documented surgical cases of the survey cohort. Each point represents one of the 76 centers, the median of each group is given by the horizontal bar. Amongst the centers with a $100 \%$ surgical success rate $(n=9)$, there were seven centers with one and two centers with two documented cases.

(10.2-44.9) years post radiotherapy), the IGF1 normalization rate was $89 \%(n=49)$ without medical treatment.

\section{Medical therapy and biochemical outcome}

In 557 patients, who were treated medically at the time of the survey, IGF1 was available. Of these patients, 480 had at least one operation, 158 were operated and had received adjunctive radiotherapy, 13 had radiotherapy without surgery, and 64 were treated only medically. Of the 557 patients $363(65.2 \%)$, had a normal IGF1. In patients who were diagnosed $>2$ years before the survey, the IGF1 normalization rate was $69.6 \%$ while it was only $38.6 \%$ in patients who had been diagnosed within $\leq 2$ years. Monotherapy with SSAs, DAs, or pegvisomant normalized IGF1 in 68.9, 53.2, and 75.3\% of the treated patients respectively. Various combination therapies resulted in a normalization rate of $53.5 \%$. In the patients who were controlled by drug monotherapy, the median dose for depot octreotide was 20 (range $5-40) \mathrm{mg}$ every 28 days $(n=182)$, for depot lanreotide 60 (range $50-120) \mathrm{mg}$ every 4 weeks $(n=27)$, for cabergoline 1.0 (range $0.125-3.5) \mathrm{mg} /$ week $(n=24)$, for bromocriptine 3.75 (range 1.25-10) $\mathrm{mg} /$ day $(n=6)$, and for pegvisomant 20 (range $5-40) \mathrm{mg} /$ day $(n=67)$.

\section{Patients with an elevated IGFI}

Three hundred and fifty-eight patients had an elevated IGF1 at their last follow-up. The distribution of IGF1 values in these patients stratified by disease duration is shown in Fig. 3. Most patients with long-standing disease had borderline or moderately elevated IGF1 (median 320 (range 156-971) ng/ml, $n=235$ ), while patients with a more recent or new diagnosis $(\leq 2$ years) had higher IGF1 levels (median 464 (range 186-1195) $\mathrm{ng} / \mathrm{ml}, n=105$ ) as could be expected.

A more detailed analysis revealed that 169 patients $(47.2 \%)$ received no drug therapy. In these 169 patients, median IGF1 was 387.5 (range 167-1195) $\mathrm{ng} / \mathrm{ml}$, whereas IGF1 was 325 (range 156-1111) $\mathrm{ng} / \mathrm{ml}(P<0.001)$ in the 189 patients who were treated either with single or combined drug therapy. The proportion of patients that received no drug therapy despite an elevated IGF1 was higher in patients who were diagnosed within $\leq 2$ years $(66.7 \%$; IGF1 597 $\pm 295 \mathrm{ng} / \mathrm{ml}, n=90)$ compared with the patients with a long-standing history (38.5\%; IGF1 $386 \pm 164 \mathrm{ng} / \mathrm{ml}$, $n=70, P<0.001)$. The medical treatment regimens used in the patients with an elevated IGF1 are depicted in Fig. 4. The median doses for patients treated by drug monotherapy were for depot octreotide 30 (range $7.5-40) \mathrm{mg}$ every 28 days $(n=78)$, for depot lanreotide 90 (range 40-120) mg every 28 days $(n=10)$, for cabergoline 1.88 (range 0.25-4.0) $\mathrm{mg} /$ week $(n=22)$, for bromocriptine 10 (range 7.5-15.0) $\mathrm{mg} /$ day $(n=3)$, and for pegvisomant 20 (range 10-40) $\mathrm{mg} /$ day $(n=22)$. With the exception of octreotide LAR $(P<0.001)$, the doses used in the uncontrolled patients were not different from those used in patients who were medically controlled. There were no differences in the drug doses between patients with a long-standing $(>2$ years) or a more recent ( $\leq 2$ years) diagnosis of acromegaly.

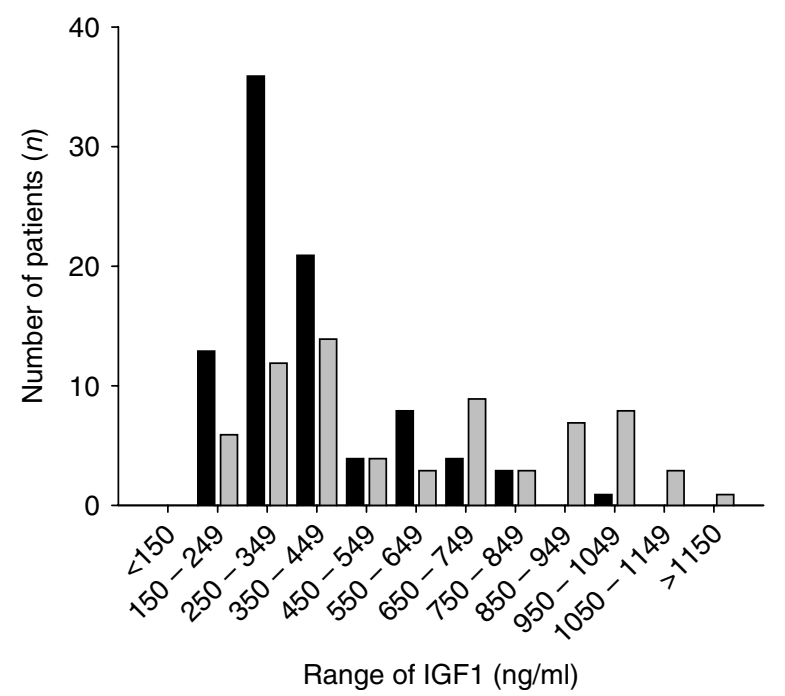

Figure 3 Histogram of IGF1 values in patients with an elevated IGF1 at the time of the survey subdivided by disease duration. Black columns, patients with long-standing disease ( $>2$ years); gray columns, patients diagnosed within $\leq 2$ years of data acquisition. 


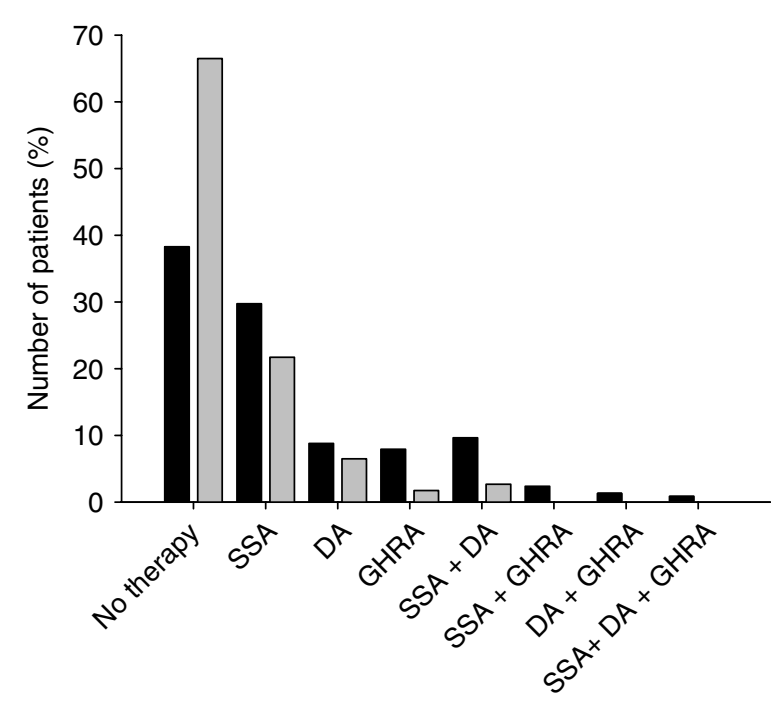

Figure 4 Medical treatment regimens in patients with elevated IGF1 subdivided by the disease duration. Black columns, patients with long-standing disease ( $>2$ years; $n=234$ ). Of these patients, 190 had at least one operation with or without adjunctive radiotherapy, seven had received radiotherapy without surgery, and 38 were treated medically only. Gray columns, patients diagnosed within $\leq 2$ years of data acquisition $(n=105)$. Of these patients, $73 \mathrm{had}$ at least one operation with or without adjunctive radiotherapy and 32 were treated medically only. SSA, somatostatin analog; DA, dopamine agonist; GHRA, GH receptor antagonist.

In order to further explore the reasons for not treating or for not stepping up medical treatment, we assessed random $\mathrm{GH}$ in patients with elevated IGF1. Random $\mathrm{GH}$ was available in $300(83.8 \%)$ of the 358 patients and was lower than $1.0 \mathrm{ng} / \mathrm{ml}(2.5 \mathrm{ng} / \mathrm{ml})$ in 63 (136) patients. As depicted in Table 2, the proportion of patients with a random $\mathrm{GH}<1$ or $2.5 \mathrm{ng} / \mathrm{ml}$ as well as the GH-levels was similar in patients with or without medical therapy. Considering only patients as clearly uncontrolled with both an elevated IGF1 and random $\mathrm{GH}$, then this would apply to $19.5 \%(\mathrm{GH} \geq 1 \mathrm{ng} / \mathrm{ml})$ or $13.5 \%(\mathrm{GH} \geq 2.5 \mathrm{ng} / \mathrm{ml})$ of the cases.

\section{Discussion}

The aim of the present analysis was to describe the biochemical outcome of patients with acromegaly under the conditions of the health care system in Germany. In the present retrospective survey, 1344 patients from the German Acromegaly Register were included. Based on a population of about 80 million and a disease prevalence of about 40-60 cases/million $(31,32)$, this cohort represents $\sim 30-40 \%$ of all acromegalic patients in Germany. The proportion of patients treated either in university or non-university hospitals or in private endocrine practices was similar to previous reports from the German Register $(25,26)$. We assume that this is a representative picture of endocrine specialist care for patients with acromegaly in Germany. Patients, however, treated only by their general practitioners are disregarded because of the selection criteria for participating centers. According to two recall studies performed at two neurosurgical centers in Germany, this group of patients might be as large as $25 \%$ of surgically treated patients (33).

In the current analysis, there was a female predominance which is consistent with previous reports from this $(25,26)$ and other registers (Table 3$)$. Women with acromegaly were significantly older than men at diagnosis which is again in accordance with the literature (31). About $80 \%$ of the patients with a documented tumor size had a macroadenoma at diagnosis further indicating that the cohort analyzed was representative for the disease (Table 3).

The latest criteria for disease control are an IGF1 level in the adjusted normal range and a random GH level $<1 \mathrm{ng} / \mathrm{ml}$ measured by an ultrasensitive GH assay (28). In this study, disease control was primarily defined by IGF1 as described in the Subjects and methods section. For financial and logistic reasons, a centralized measurement of IGF1 on a nationwide and continuous basis is not feasible in the current setting of the German Acromegaly Register. Local measurement of IGF1 and center-specific evaluation appears appropriate in an epidemiologic study, as this approach controls for some of the well-known variations between IGF1 assays $(34,35)$ and as decisions to adjust treatment strategies in daily routine are based on locally available IGF1. As normalization of IGF1 is associated with an improvement in clinical symptoms and comorbidities and markedly reduces the mortality risk $(2,3,4,27)$, some centers guide their treatment decisions mainly, if not exclusively, on IGF1 levels. This may explain why random $\mathrm{GH}$ was only available for $81 \%$ of the patients at the last follow-up (IGF1 95\%). Furthermore, the pulsatile nature of $\mathrm{GH}$ secretion may persist in controlled acromegaly and thus random GH could lead to misclassifications (27). In about $20-30 \%$ of the patients, discordance of $\mathrm{GH}$ and IGF1 has been

Table 2 Random GH in patients with elevated IGF1 with or without medical therapy stratified by two different thresholds for random GH (1 and $2.5 \mathrm{ng} / \mathrm{ml})$.

\begin{tabular}{lllll}
\hline & GH $<\mathbf{1} \mathbf{~ n g} / \mathbf{m l}$ & GH $\geq \mathbf{1} \mathbf{~ n g} / \mathbf{m l}$ & GH $<\mathbf{2 . 5} \mathbf{~ n g} / \mathbf{m l}$ & GH $\geq \mathbf{2 . 5} \mathbf{~ n g} / \mathbf{m l}$ \\
\hline With medical therapy $(n=143)$ & $31(21.7 \%)$ & $112(78.3 \%)$ & $68(47.5 \%)$ & $75(52.5 \%)$ \\
Median GH (range) & $0.65(0.20-0.98)$ & $3.75(1.0-108)$ & $1.09(0.20-2.40)$ & $5.20(2.50-108)$ \\
Without medical therapy $(n=157)$ & $32(20.4 \%)$ & $125(79.6 \%)$ & $68(43.3 \%)$ & $89(56.7 \%)$ \\
Median GH (range) & $0.52(0.06-0.98)$ & $3.90(1.0-145)$ & $1.0(0.06-2.31)$ & $6.63(2.50-145)$ \\
\hline
\end{tabular}




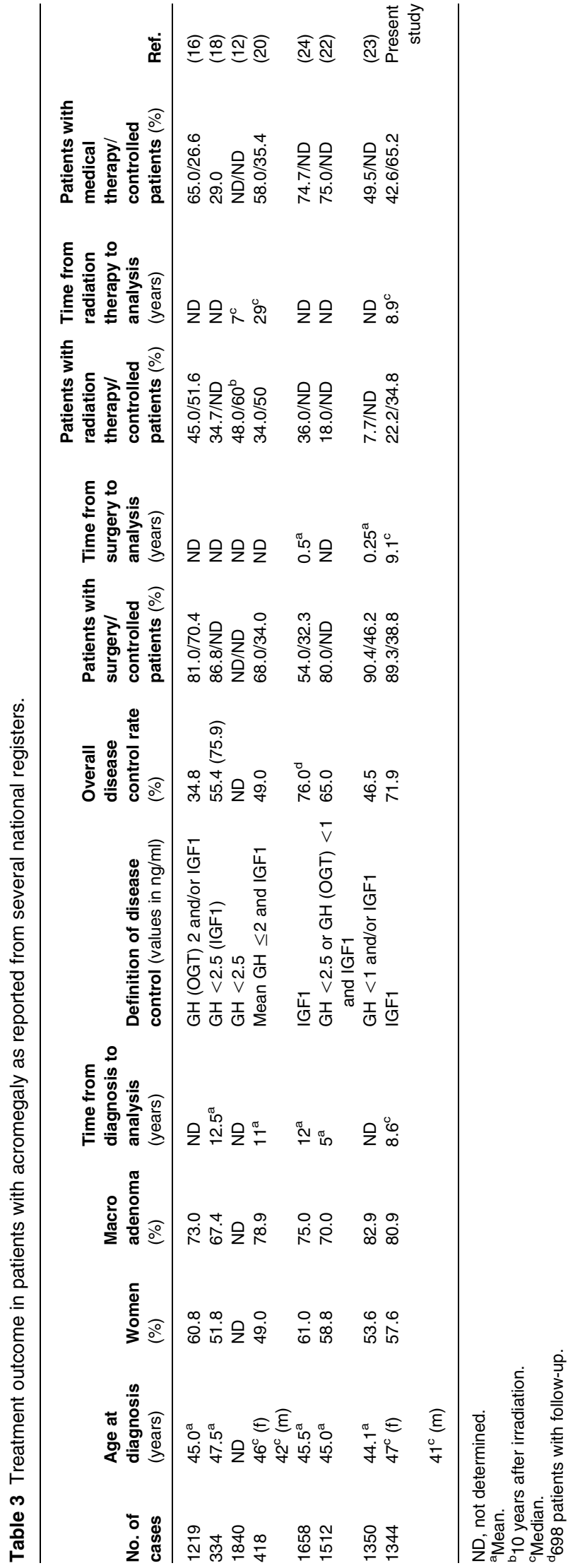

described after treatment $(36,37,38)$. In most cases, GH is normal and IGF1 is elevated, but in some cases it is just the opposite $(36,39)$. So far there is no clear evidence that the mortality risk is increased in patients with discordant GH and IGF1 levels and there is no consensus as to whether these patients require treatment (28). Therefore, we may rather underestimate than overestimate the proportion of patients with a 'safe' GH status by just using IGF1 as the criterion for disease activity.

Of the patients with available IGF1, $72 \%$ were controlled. This percentage increased to $77 \%$ in the patients with long-standing disease ( $>2$ years), while patients with a more recent diagnosis ( $\leq 2$ years) were controlled in only $47 \%$ of cases as expected. This is similar to a very recent analysis from Spain (24) and to data from Finland, where diagnostic procedures and treatment are centralized in five university hospitals (18). By contrast, comparable cure rates from the Belgian registry were considerably lower, even if only the cases with normal IGF1 were considered (20). In the Belgian survey, however, classification was done by centralized measurement of IGF1, which allows a more standardized evaluation of disease control over different centers (20).

\section{Surgery}

Surgery is currently the only option to cure the disease, and if this goal can be attained, surgery is by far the most cost-effective treatment. According to current as well as previous guidelines, transsphenoidal surgery is the treatment of first choice $(5,40)$. Approximately $90 \%$ of our cohort underwent surgery at least once, mostly by the transsphenoidal route. This percentage is in the range of that reported from the Spanish registry $(81 \%)(16)$, but higher than those reported from the Belgian cohort (68\%) (20) or the UK National Acromegaly Register (68.7\%) (41). At the time of the survey, $38.8 \%$ of the operated patients had a normal IGF1 without further treatment. This is less than the postoperative IGF1 normalization rate of $67.2 \%$ reported previously from the same register (19). While the latter analysis was performed after a median of 9.8 months post surgery, IGF1 in the present study was evaluated after 9 years, which also comprises patients with disease recurrence and thus better reflects the long-term surgical success rates. Furthermore, the number of patients in this study was more than twice as high as in the previous analysis. This 'long-term' surgical control rate is similar to the one published from AcroBel (20), but less than the 70\% reported from Spain (16). In any case, surgical success rates were lower than those published from experienced neurosurgical centers which range between 42 and $82 \%$ (7). However, criteria for disease control and observation periods differ, which hampers comparisons between studies (Table 3). 
In 939 patients, the neurosurgical unit of the first operation was documented. In these patients operations were performed in 76 different surgical centers. The number of patients from the present cohort treated by these centers ranged from 1 to 110. Experience is a well accepted and important determinant of surgical success and the number of operations might be used as a surrogate parameter $(9,41,42)$. Although the documented cases in the register do not necessarily reflect the total number of pituitary operations performed by each center, there was a significant trend of higher cure rates in centers with more cases. Nevertheless, the scatter of surgical success rates was considerable even in the large centers with a median control rate of $\sim 50 \%$. To further improve the postsurgical outcome on a nationwide perspective, it appears therefore reasonable to concentrate surgery of acromegaly patients in the hands of a smaller number of specialized centers. Such a strategy substantially improved the surgical results in the UK (41).

\section{Radiation}

Radiation therapy, although effective in controlling tumor growth and lowering GH-excess, has been recently viewed as a third-line treatment because of still unsolved long-term safety issues (5). In the present cohort, irradiation had been applied in $22 \%$ of cases almost exclusively as an adjunctive therapy after surgery. This is less than the numbers in the Belgian register and about half of those published from Spain or the UK (Table 3). A very recent publication from the Spanish Acromegaly Registry, however, documented a decline of the use of radiotherapy to $11.9 \%$ in patients diagnosed after 2000 (24). Overall, about 35\% of the patients with adjunct radiotherapy had a normal IGF1 after a median follow-up period of 8.9 years. This response rate is somewhat less than those reported from other large cohorts with similar observation periods (12) but similar to the one from the Belgian registry $(10,20)$. Maximum response occurs 10-15 years after irradiation. In patients who had their radiotherapy more than 10 years before the survey, normalization of IGF1 was almost $90 \%$, which is in line with data from the UK National Acromegaly Register (12).

\section{Medical treatment}

Almost $43 \%$ of the patients received medical treatment at the time of the survey. As reported from other registers, SSA were the most frequently used drugs $(16,20)$. Most patients were on drug monotherapy, which could achieve disease control in the majority of patients treated with the respective compounds ranging from 53 to $75 \%$. Although there was an overall trend for higher drug doses in patients with uncontrolled disease, this was only statistically significant in patients treated with octreotide LAR. Thus, there is room for up-titrating medical therapy in the majority of patients with uncontrolled disease under ongoing medical treatment. A similar phenomenon has been reported from the observational registry of the GHRA pegvisomant (43). In order to further enhance the success rates of medical therapies, it is therefore important to understand the reasons for the failure of dose titration. One reason might be discordant biochemical information about disease activity as in $20 \%$ of patients with an elevated IGF1, random GH was below $1 \mathrm{ng} / \mathrm{ml}$ and in $43 \%$ it was below $2.5 \mathrm{ng} / \mathrm{ml}$.

\section{Uncontrolled patients}

About 23\% of the patients with long-standing disease had an elevated IGF1. Patients with a more recent diagnosis had an elevated IGF1 in more than $50 \%$ of the cases, which, however, also included patients with newly diagnosed acromegaly. Accordingly, the distribution of elevated IGF1 levels was shifted more toward the normal range in patients with long-standing disease. Despite elevated IGF1 levels, however, the majority did not receive any further treatment. The most recent guidelines for the management of acromegaly suggest making therapeutic decisions according to an individualized biochemical and clinical assessment (5). Additional therapy should be considered if IGF1 and GH are elevated, and clinical judgment should be used if IGF1 and GH measurements are discrepant (5). About $80 \%$ of the patients with an elevated IGF1 had a random $\mathrm{GH} \geq 1 \mathrm{ng} / \mathrm{ml}$, and $55 \%$ had a random $\mathrm{GH}$ $\geq 2.5 \mathrm{ng} / \mathrm{ml}$. Thus, $19.5 \%(\mathrm{GH} \geq 1 \mathrm{ng} / \mathrm{ml})$ or $13.5 \%$ $(\mathrm{GH} \geq 2.5 \mathrm{ng} / \mathrm{ml})$ of the patients were clearly uncontrolled. The latter threshold for random $\mathrm{GH}$ $(<2.5 \mathrm{ng} / \mathrm{ml})$ has been used in a recent overview about the clinical, quality of life, and economic value of acromegaly disease control (2). Although there are many unanswered questions about the benefits regarding individual morbidities, health-related quality of life, and cost of controlled vs uncontrolled disease $(2,44$, $45)$, there is no doubt about the overall advantage of disease control for long-term morbidity and mortality. Understanding the reasons for not treating or not up-titrating an ongoing medical therapy in clearly uncontrolled patients should be investigated in a future project in order to further improve the long-term outcome in acromegaly patients.

\section{Conclusions}

A retrospective database like the German Acromegaly Register clearly has limitations but reflects the real life outcome under routine conditions. The results provide important information about the management and outcome of acromegalic patients under the conditions of the health care system in Germany. Germany as the most populous country in Europe has a non-centralized 
health care system. The care of acromegalic patients is distributed over many academic and non-academic hospital settings, as well as private practices. We assume that the results of the present survey provide a representative picture of endocrine specialist care for patients with acromegaly in Germany. Overall, surgical success rates were moderate and could be enhanced by concentrating surgery of acromegaly patients in the hands of a smaller number of specialized centers. After applying the most recent criteria for disease control, $20 \%$ of the patients were still uncontrolled. Commencing or up-titrating ongoing drug therapy and fully exploiting medical treatment options, especially in patients not controlled by surgery, could further improve the long-term outcome of acromegaly patients.

\section{Declaration of interest}

The authors declare that there is no conflict of interest that could be perceived as prejudicing the impartiality of the research reported.

\section{Funding}

The German Acromegaly Register is supported by unrestricted grants from Novartis Pharma GmbH, Nuremberg, Germany; Ipsen Pharma $\mathrm{GmbH}$; Ettlingen, Germany, and from Pfizer Deutschland $\mathrm{GmbH}$, Berlin, Germany.

\section{Acknowledgements}

The authors thank all participants of the German Acromegaly Register: K Badenhoop, G Bender, C Berg, H Biering, U Bogner, S R Bornstein, K Cissewski, F Demtröder, M Droste, M Engelbach, J Feldkamp, R Finke, B Friesenhahn-Ochs, T Gain, B Gallwitz, A Gerhardt, M Grußendorf, D Haaser, R Hampel, S Hering, J Honegger, J Jacobeit, O Janßen, C Jaursch-Hancke, E Jungmann, U Kajdan, P Kann, A Kastrinaki, H Klein, D Klingmüller, E Kornely, H Lehnert, M M Lerch, C Loessner, C Metzner, J Meuser, A Meyer, H Mönig, A Müller, J Pichl, U Plöckinger, O Ploner, M Quinkler, K Reschke, M Ritter, A Schäffler, C Schöfl, J Schopohl, J Seufert, C Sievers, H Siggelkow, C Streetz-van der Werf, C J Strasburger, A Tönjes, H Willenberg, A Zimmermann, and K Zumbusch.

\section{References}

1 Melmed S. Medical progress: acromegaly. New England Journal of Medicine 2006355 2558-2573. (doi:10.1056/NEJMra062453)

2 Ben Shlomo A, Sheppard MC, Stephens JM, Pulgar S \& Melmed S. Clinical, quality of life, and economic value of acromegaly disease control. Pituitary 201114 284-294. (doi:10.1007/s11102-0110310-7)

3 Holdaway IM, Bolland MJ \& Gamble GD. A meta-analysis of the effect of lowering serum levels of GH and IGF-I on mortality in acromegaly. European Journal of Endocrinology 2008159 89-95. (doi:10.1530/EJE-08-0267)

4 Dekkers OM, Neelis KJ, de Keizer RJ, Voormolen JH, Pereira AM \& Romijn JA. Nonfunctioning pituitary macroadenomas: diagnosis, treatment and follow-up. Nederlands Tijdschrift Voor Geneeskunde 2008152 792-796.

5 Melmed S, Colao A, Barkan A, Molitch M, Grossman AB, Kleinberg D, Clemmons D, Chanson P, Laws E, Schlechte J et al. Guidelines for acromegaly management: an update. Journal of Clinical Endocrinology and Metabolism 200994 1509-1517. (doi:10.1210/jc.2008-2421)
6 Kreutzer J, Vance ML, Lopes MB \& Laws ER Jr. Surgical management of GH-secreting pituitary adenomas: an outcome study using modern remission criteria. Journal of Clinical Endocrinology and Metabolism $2001 \quad \mathbf{8 6} \quad 4072-4077$. (doi:10.1210/jc.86.9.4072)

7 Nomikos P, Buchfelder M \& Fahlbusch R. The outcome of surgery in 668 patients with acromegaly using current criteria of biochemical 'cure'. European Journal of Endocrinology 2005152 379-387. (doi:10.1530/eje.1.01863)

8 Lüdecke DK \& Abe T. Transsphenoidal microsurgery for newly diagnosed acromegaly: a personal view after more than 1,000 operations. Neuroendocrinology 200683 230-239. (doi:10.1159/ 000095533)

9 Laws ER. Surgery for acromegaly: evolution of the techniques and outcomes. Reviews in Endocrine \& Metabolic Disorders 20089 67-70. (doi:10.1007/s11154-007-9064-y)

10 Barrande G, Pittino-Lungo M, Coste J, Ponvert D, Bertagna X, Luton JP \& Bertherat J. Hormonal and metabolic effects of radiotherapy in acromegaly: long-term results in 128 patients followed in a single center. Journal of Clinical Endocrinology and Metabolism 200085 3779-3785. (doi:10.1210/jc.85.10.3779)

11 Minniti G, Jaffrain-Rea ML, Osti M, Esposito V, Santoro A, Solda F, Gargiulo P, Tamburrano G \& Enrici RM. The long-term efficacy of conventional radiotherapy in patients with $\mathrm{GH}$-secreting pituitary adenomas. Clinical Endocrinology $2005 \quad 62$ 210-216. (doi:10.1111/j.1365-2265.2005.02199.x)

12 Jenkins PJ, Bates P, Carson MN, Stewart PM \& Wass JA. Conventional pituitary irradiation is effective in lowering serum growth hormone and insulin-like growth factor-I in patients with acromegaly. Journal of Clinical Endocrinology and Metabolism 2006 91 1239-1245. (doi:10.1210/jc.2005-1616)

13 Attanasio R, Baldelli R, Pivonello R, Grottoli S, Bocca L, Gasco V, Giusti M, Tamburrano G, Colao A \& Cozzi R. Lanreotide $60 \mathrm{mg}$, a new long-acting formulation: effectiveness in the chronic treatment of acromegaly. Journal of Clinical Endocrinology and Metabolism $2003 \quad \mathbf{8 8}$ 5258-5265. (doi:10.1210/jc.2003030266)

14 Castinetti F, Taieb D, Kuhn JM, Chanson P, Tamura M, Jaquet P, Conte-Devolx B, Regis J, Dufour H \& Brue T. Outcome of gamma knife radiosurgery in 82 patients with acromegaly: correlation with initial hypersecretion. Journal of Clinical Endocrinology and Metabolism 200590 4483-4488. (doi:10.1210/jc.2005-0311)

15 Jezkova J, Marek J, Hana V, Krsek M, Weiss V, Vladyka V, Lisak R, Vymazal J \& Pecen L. Gamma knife radiosurgery for acromegaly long-term experience. Clinical Endocrinology 200664 588-595. (doi:10.1111/j.1365-2265.2006.02513.x)

16 Mestron A, Webb SM, Astorga R, Benito P, Catala M, Gaztambide S, Gomez JM, Halperin I, Lucas-Morante T, Moreno B et al. Epidemiology, clinical characteristics, outcome, morbidity and mortality in acromegaly based on the Spanish Acromegaly Registry (Registro Espanol de Acromegalia, REA). European Journal of Endocrinology $2004 \quad 151$ 439-446. (doi:10.1530/eje.0.1510439)

17 Ayuk J, Clayton RN, Holder G, Sheppard MC, Stewart PM \& Bates AS. Growth hormone and pituitary radiotherapy, but not serum insulin-like growth factor-I concentrations, predict excess mortality in patients with acromegaly. Journal of Clinical Endocrinology and Metabolism $2004 \quad 89$ 1613-1617. (doi:10.1210/jc.2003-031584)

18 Kauppinen-Mäkelin R, Sane T, Reunanen A, Valimaki MJ, Niskanen L, Markkanen H, Loyttyniemi E, Ebeling T, Jaatinen P, Laine $\mathrm{H}$ et al. A nationwide survey of mortality in acromegaly. Journal of Clinical Endocrinology and Metabolism 200590 4081-4086. (doi:10.1210/jc.2004-1381)

19 Reincke M, Petersenn S, Buchfelder M, Gerbert B, Skrobek-Engel G, Franz H, Lohmann R \& Quabbe HJ. The German Acromegaly Registry: description of the database and initial results. Experimental and Clinical Endocrinology \& Diabetes 2006114 498-505. (doi:10.1055/s-2006-948313)

20 Bex M, Abs R, T'Sjoen G, Mockel J, Velkeniers B, Muermans K \& Maiter D. AcroBel - the Belgian registry on acromegaly: a survey of 
the 'real-life' outcome in 418 acromegalic subjects. European Journal of Endocrinology 2007157 399-409. (doi:10.1530/EJE07-0358)

21 Fieffe S, Morange I, Petrossians P, Chanson P, Rohmer V, Cortet C, Borson-Chazot F, Brue T \& Delemer B. Diabetes in acromegaly, prevalence, risk factors, and evolution: data from the French Acromegaly Registry. European Journal of Endocrinology 2011164 877-884. (doi:10.1530/EJE-10-1050)

22 Arosio M, Reimondo G, Malchiodi E, Berchialla P, Borraccino A, De Marinis L, Pivonello R, Grottoli S, Losa M, Cannavo S et al. Predictors of morbidity and mortality in acromegaly: an Italian survey. European Journal of Endocrinology 2012167 189-198.

23 Kwon O, Song YD, Kim SY \& Lee EJ. Nationwide survey of acromegaly in South Korea. Clinical Endocrinology 2012. In press. (doi:10.1111/cen.12020)

24 Sesmilo G, Gaztambide S, Venegas E, Pico A, Del Pozo C, Blanco C, Torres E, Alvarez-Escola C, Fajardo C, Garcia R et al. Changes in acromegaly treatment over four decades in Spain: analysis of the Spanish Acromegaly Registry (REA). Pituitary 2012. In press. (doi:10.1007/s11102-012-0384-x)

25 Petersenn S, Buchfelder M, Reincke M, Strasburger CM, Franz H, Lohmann R, Quabbe HJ \& Plöckinger U. Results of surgical and somatostatin analog therapies and their combination in acromegaly: a retrospective analysis of the German Acromegaly Register. European Journal of Endocrinology $2008 \quad 159$ 525-532. (doi:10.1530/EJE-08-0498)

26 Petersenn S, Buchfelder M, Gerbert B, Franz H, Quabbe HJ, Schulte HM, Grussendorf M \& Reincke M. Age and sex as predictors of biochemical activity in acromegaly: analysis of 1485 patients from the German Acromegaly Register. Clinical Endocrinology 200971 400-405. (doi:10.1111/j.1365-2265.2009. 03547.x)

27 Brabant G. Insulin-like growth factor-I: marker for diagnosis of acromegaly and monitoring the efficacy of treatment. European Journal of Endocrinology 2003148 S15-S20. (doi:10.1530/eje.0. 148S015)

28 Giustina A, Chanson P, Bronstein MD, Klibanski A, Lamberts S, Casanueva FF, Trainer P, Ghigo E, Ho K \& Melmed S. A consensus on criteria for cure of acromegaly. Journal of Clinical Endocrinology and Metabolism $2010 \quad 95$ 3141-3148. (doi:10.1210/jc. 2009-2670)

29 Arafat AM, Möhlig M, Weickert MO, Perschel FH, Purschwitz J, Spranger J, Strasburger CJ, Schöfl C \& Pfeiffer AF. Growth hormone response during oral glucose tolerance test: the impact of assay method on the estimation of reference values in patients with acromegaly and in healthy controls, and the role of gender, age, and body mass index. Journal of Clinical Endocrinology and Metabolism 200893 1254-1262. (doi:10.1210/jc.2007-2084)

30 Bidlingmaier M \& Freda PU. Measurement of human growth hormone by immunoassays: current status, unsolved problems and clinical consequences. Growth Hormone \& IGF Research 2010 20 19-25. (doi:10.1016/j.ghir.2009.09.005)

31 Holdaway IM \& Rajasoorya C. Epidemiology of acromegaly. Pituitary 19992 29-41. (doi:10.1023/A:1009965803750)

32 Schneider HJ, Sievers C, Saller B, Wittchen HU \& Stalla GK. High prevalence of biochemical acromegaly in primary care patients with elevated IGF-1 levels. Clinical Endocrinology 200869 432-435. (doi:10.1111/j.1365-2265.2008.03221.x)
33 Psaras T, Milian M, Hattermann V, Gallwitz B, Freiman T \& Honegger J. Aftercare in patients with Cushing's disease and acromegaly: is there room for improvement? Acta Neurochirurgica 2010152 271-278. (doi:10.1007/s00701-009-0544-6)

34 Frystyk J, Freda P \& Clemmons DR. The current status of IGF-I assays - a 2009 update. Growth Hormone \& IGF Research 201020 8-18. (doi:10.1016/j.ghir.2009.09.004)

35 Bidlingmaier M. Pitfalls of insulin-like growth factor I assays. Hormone Research 200971 (Suppl 1) 30-33. (doi:10.1159/ $000178034)$

36 Alexopoulou O, Bex M, Abs R, T’Sjoen G, Velkeniers B \& Maiter D. Divergence between growth hormone and insulin-like growth factor-I concentrations in the follow-up of acromegaly. Journal of Clinical Endocrinology and Metabolism 200893 1324-1330. (doi:10.1210/jc.2007-2104)

37 Arafat AM, Müller L, Möhlig M, Mayr B, Kremenevskaya N, Pfeiffer AF, Buchfelder M \& Schöfl C. Comparison of oral glucose tolerance test (OGTT) $100 \mathrm{~g}$ with OGTT $75 \mathrm{~g}$ for evaluation of acromegalic patients and the impact of gender on test reproducibility. Clinical Endocrinology 201175 685-691. (doi:10.1111/j. 1365-2265.2011.04108.x)

38 Carmichael JD, Bonert VS, Mirocha JM \& Melmed S. The utility of oral glucose tolerance testing for diagnosis and assessment of treatment outcomes in 166 patients with acromegaly. Journal of Clinical Endocrinology and Metabolism 200994 523-527. (doi:10. 1210/jc.2008-1371)

39 Freda PU. Monitoring of acromegaly: what should be performed when GH and IGF-1 levels are discrepant? Clinical Endocrinology 200971 166-170. (doi:10.1111/j.1365-2265.2009.03556.x)

40 Giustina A, Bronstein MD, Casanueva FF, Chanson P, Ghigo E, Ho KK, Klibanski A, Lamberts S, Trainer P \& Melmed S. Current management practices for acromegaly: an international survey. Pituitary 201114 125-133. (doi:10.1007/s11102-0100269-9)

41 Bates PR, Carson MN, Trainer PJ \& Wass JA. Wide variation in surgical outcomes for acromegaly in the UK. Clinical Endocrinology 200868 136-142. (doi:10.1111/j.1365-2265.2007.03012.x)

42 Erturk E, Tuncel E, Kiyici S, Ersoy C, Duran C \& Imamoglu S. Outcome of surgery for acromegaly performed by different surgeons: importance of surgical experience. Pituitary 20058 93-97. (doi:10.1007/s11102-005-3280-9)

43 Trainer PJ. ACROSTUDY: the first 5 years. European Journal of Endocrinology 2009161 (Suppl 1) S19-S24. (doi:10.1530/EJE09-0322)

44 Davi' MV, Dalle CL, Giustina A, Ferrari M, Frigo A, Lo Cascio V \& Francia G. Sleep apnoea syndrome is highly prevalent in acromegaly and only partially reversible after biochemical control of the disease. European Journal of Endocrinology 2008159 533-540. (doi:10.1530/EJE-08-0442)

45 van Thiel SW, Bax JJ, Biermasz NR, Holman ER, Poldermans D, Roelfsema F, Lamb HJ, van der Wall EE, Smit JW, Romijn JA et al. Persistent diastolic dysfunction despite successful long-term octreotide treatment in acromegaly. European Journal of Endocrinology 2005153 231-238. (doi:10.1530/eje.1.01955)

Received 13 July 2012

Revised version received 21 September 2012

Accepted 19 October 2012 